\title{
References
}

1. Avanesov V. S. Formy testovyh zadanij. - Moskva: Centr testirovania, 2006. - $156 \mathrm{p}$.

2. Andrienko O. S. Diagnostuvannia v navczalnomu procesi // Visnyk Zaporizkogo dergavnogo universytetu.. - 2002.- №1.- P. 1-5.

3. Gensiorska M. M. Adaptyvne testuvannia v osviti // Informacijno-komunikacijni tehnologiji v osviti. -2014 . - №1

4. Gladka L. I. Systemnyj pidhid do ocinky jakosti znan' u formi kompiuternogo testuvannia. Naukovuj visnyk Donbasu, 2014. http://nvd.luguniv.edu.ua/archiv/NN26/index.html.

5. Eremeevych M. O. Kompjuterni systemy testuvannia ta jih analiz // Molodyj vchenyj. -2016 . - P. 330-332.

6. Ingekamp K Pedagogicheskaja diagnostika. - M. : Pedagogika, 1991. $-240 \mathrm{p}$.

7. Kornycka Ju. A. Kompiuterne testuvannia $\mathrm{v}$ navczalnomu procesi VNZ // Visnyk Cherkaskogo universytetu: nauk.zurnal. - Cherkasy, 2013. -№ 26 (279). - P. 32-37.

8. Krystopchuk T. Je., Melnyk Ju. V. Monitoryng stanu vykladannia navczalnogo predmetu: Algorutm vyvchennia. - Molodyj vchenyj, 2018. - P.43-45/

9. Lukina T.O. Pedagogichna diagnostyka: zavdannia, metody, instrument. - Kyiv : Proekt "Rivnyj dustup do jakisnoji osvity v Ukrajini", 2007. -59 p.

10. Onopchenko G. V. Internet-testuvannia v informacijnomu socialnomu seredovyshchi jak instrument rozvytku subjektiv osvitniogo procesu. - Kyiv : Instytut obdarovanoji dytyny NAPN Ukrajiny, 2013.

Одержкано статтю: 25.09.2019

Прийнято до друку: 18.10.2019

УДК $373.3 .016: 81-028.31$

DOI: $10.15330 /$ esu. 17.338-346

\author{
Лариса Круль, \\ кандидат педагогічних наук, доцент, \\ ДВНЗ "Прикарпатський національний \\ університет імені Василя Стефаника" \\ (м. Івано-Франківськ, Україна) \\ Larysa Krul, \\ Candidate of pedagogical sciences $(\mathrm{PhD})$, \\ Associate Professor, Vasyl Stefanyk Precarpathian \\ National university (Ivano-Frankivsk, Ukraine) \\ larisa-krul@ukr.net
}

Степан Недільський, кандидат педагогічних наук, доцент, ДВНЗ “Прикарпатський національний університет імені Василя Стефаника" (м. Івано-Франківськ, Україна)

Stepan Nedilskyi,

Candidate of pedagogical sciences $(\mathrm{PhD})$, Associate Professor, Vasyl Stefanyk Precarpathian National university (Ivano-Frankivsk, Ukraine) nedilsky.s@gmail.com

\section{ОСОБЛИВОСТІ ОРГАНІЗАЦЇ̈ МОВНО-ЛІТЕРАТУРНОЇ ОСВІТИ МОЛОДШИХ ШКОЛЯРІВ В УМОВАХ НУШ}

\author{
PECULIARITIES OF THE ORGANIZATION OF LINGUISTIC AND LITERARY \\ EDUCATION OF YOUNGER PUPILS IN THE CONDITIONS OF NEW UKRAINIAN \\ SCHOOL
}

В статті окреслено особливості організачії мовно-літературної освіти молодиих иколярів в умовах Нової украӥнської иколи з урахуванням нормативних документів, типових освітніх програм, методичних рекомендачій, авторських навчальних програм, підручників та посібників. 
Обгрунтовано, що мовно-літературну освітню галузь зосереджено на вивченні дітьми рідної, водночас й іноземной мови задля формування іниомовної комунікативної компетентності. Відтак розиирюеться поле комунікаиії, передбачено потениійні можливості й потреби особистості у міжкультурному спілкуванні.

Узагальнено, щуо особливістю організачії мовно-літературиої освіти молодиих иколярів стають уміния учителя, який обирас за якою програмою навчати учнів, а відтак визначас пріоритети навчання: традичійне чи інтегроване, звичне чи інновачійне, спрямоване на формувания знань чи зоріситоване на формувания практичних умінь і навичок, а відтак і реалізацію діяльнісного підходу.

Ключові слова: Державший стандарт початкової освіти, мовно-літературиа освітня галузь, комунікативна компетентність, діяльнісний підхід, Нова українська школа, авторські навчальні програми, змістові лінії предмета "Украйнська мова".

The article describes the peculiarities of the organization of linguistic and literary education of younger students in the conditions of the New Ukrainian School. The author used the normative documents, typical educational programs, methodical recommendations, author's educational programs, textbooks and manuals.

The author has substantiated that the linguistic and literary education sector focuses on the study of mother tongue and, at the same time, foreign language for the formation of foreign language communication skills. Thus, it was expanded the field of communication, the potentials and needs of the individual in intercultural communication are foreseen.

The formed communicative and reading competence of the child becomes the purpose of studying the Ukrainian language and literature.

The implementation of the linguistic and literary education sector has been implemented in textbooks that have been offered for more than ten, but for the most part they do not meet all the requirements of the New Ukrainian School.

The purpose of the research is to substantiate the peculiarities of the organization of linguistic and literary education of younger students in the conditions of the New Ukrainian School

It has been proved that the linguistic and literary education branch is aimed at the comprehensive development of the child and the formation of one of the most important competences - communicative. Being able to speak is an important feature of a person, regardless of their profession. Mastery of the word enables interaction in society, sharing of own thoughts and impressions between people, ability to defend one 's own beliefs, avoid misunderstandings, etc.

Generally speaking, the peculiarity of the organization of linguistic and literary education of younger students is the ability of the teacher who chooses which program to teach students, and therefore determines the priorities of learning: traditional or integrated, habitual or innovative, aimed at forming knowledge or focused on the formation of skills, practical and therefore the implementation of a business approach.

Key words: State standard of primary education, linguistic and literary education, communicative competence, activity approach, New Ukrainian School, author's educational programs, content lines of the subject "Ukrainian language".

Постанова проблеми. Мовно-літературна освітня галузь спрямована на всебічний розвиток дитини і формування в учнів НУШ однієї із найважливіших компетентностей - комунікативної. Уміння зв'язно висловлюватися потрібне кожній людині, незалежно від iі професії. Володіння словом дає можливість поділитися знаннями, власними думками та враженнями з людьми, відстоювати свої переконання, уникати непорозумінь. У період становлення особистості молодшого школяра відбувається оволодіння мовою і мовленням, які є засобом пізнання, спілкування, виховання та розвитку, самовираження, утвердження в суспільстві. Саме тому актуальною є проблема якісної організації мовно-літературної освіти молодших школярів в умовах НУШ.

Окреслити особливості організації мовно-літературної освіти молодших школярів в умовах НУШ можливо за умови грунтовного дослідження нормативних 
документів, типових освітніх програм НУШ, методичних рекомендації авторів навчальних програм, підручників, посібників (Н. Бібік, М. Вашуленко, О. Савченко, Р. Шияна та ін.) та практичного досвіду учителів-практиків.

Аналіз наукових досліджень і публікацій. У Державному стандарті початкової освіти чітко окреслено: до ключових компетентностей належить “вільне володіння державною мовою, що передбачає уміння усно і письмово висловлювати свої думки, почуття, чітко та аргументовано пояснювати факти, а також любов до читання, відчуття краси слова, усвідомлення ролі мови для ефективного спілкування та культурного самовираження, готовність вживати українську мову як рідну в різних життєвих ситуаціях; здатність спілкуватися рідною (у разі відмінності від державної) та іноземними мовами, що передбачає активне використання рідної мови в різних комунікативних ситуаціях, зокрема в побуті, освітньому процесі, культурному житті громади, можливість розуміти прості висловлювання іноземною мовою, спілкуватися нею у відповідних ситуаціях, оволодіння навичками міжкультурного спілкування" [1]. На реалізацію поставлених завдань і досягнення цілей спрямовані й запропоновані колективами педагогів під керівництвом О. Савченко та Р. Шияна навчальні програми, за якими навчаються учні сучасних українських шкіл.

Аналізуючи діючий Державний стандарт початкової освіти, зауважуємо, що мовно-літературна галузь спрямована не тільки на формування комунікативної компетентності учнів, а й загалом на "розвиток особистості здобувачів освіти засобами різних видів мовленнєвої діяльності; здатності спілкуватися українською мовою, мовами відповідних корінних народів і національних меншин для духовного, культурного i національного самовираження, користуватися ними в особистому i суспільному житті, міжкультурному діалозі; збагачення емоційно-чуттєвого досвіду, розвиток мовленнєво-творчих здібностей" [1].

У НУШ мовно-літературна освітня галузь зосереджено на вивченні рідної, водночас й іноземної мови задля формування іншомовної комунікативної компетентності. Відтак розширюється поле комунікації, передбачено потенційні можливості й потреби особистості у міжкультурному спілкуванні.

Сформована комунікативна й читацька компетентності дитини - мета вивчення української мови та літератури, мов та літератур відповідних корінних народів і національних меншин. Досягненню означеної мети сприяє низці чинників (рис.1).

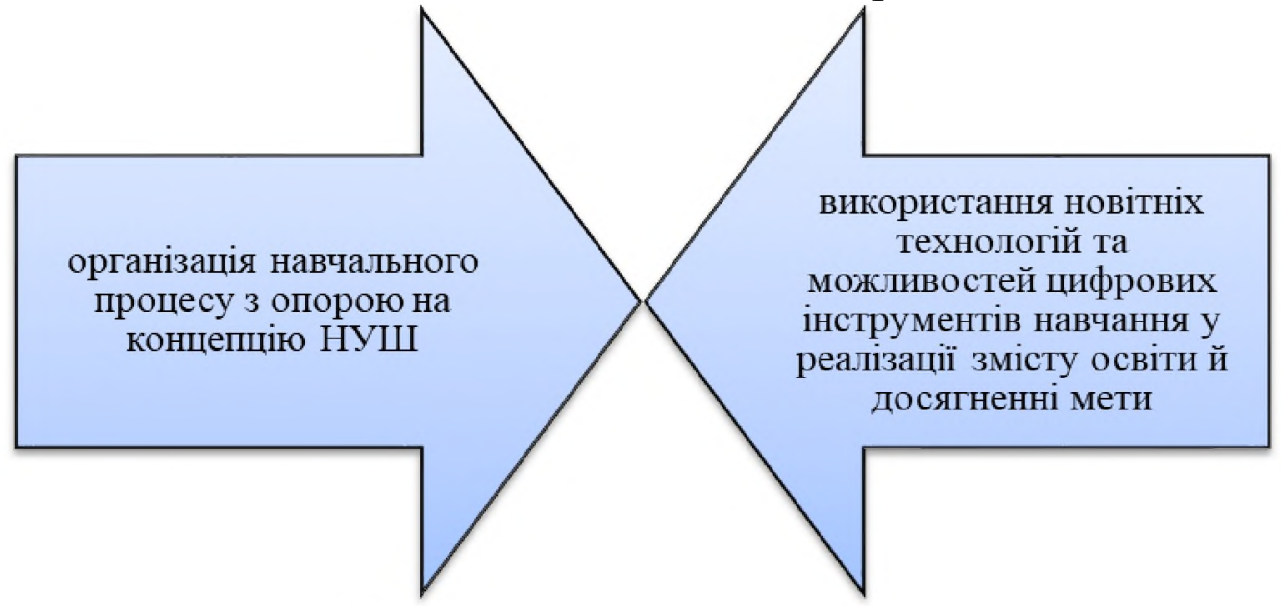

Складено автором за [1].

Рис. 1. Чинники формування комунікативної й читацької компетентності дитини 
Концепція Нової української школи зосереджує увагу на основних положеннях щодо освіти (формування компетентностей) (рис.2).

Новий зміст освіти, оснований на формуванні компетентностей, потрібннх дтя успішної самореалізації в суспільстві

Умотивованнй учитель, якнй має свободу творчості й розвнвається професійно

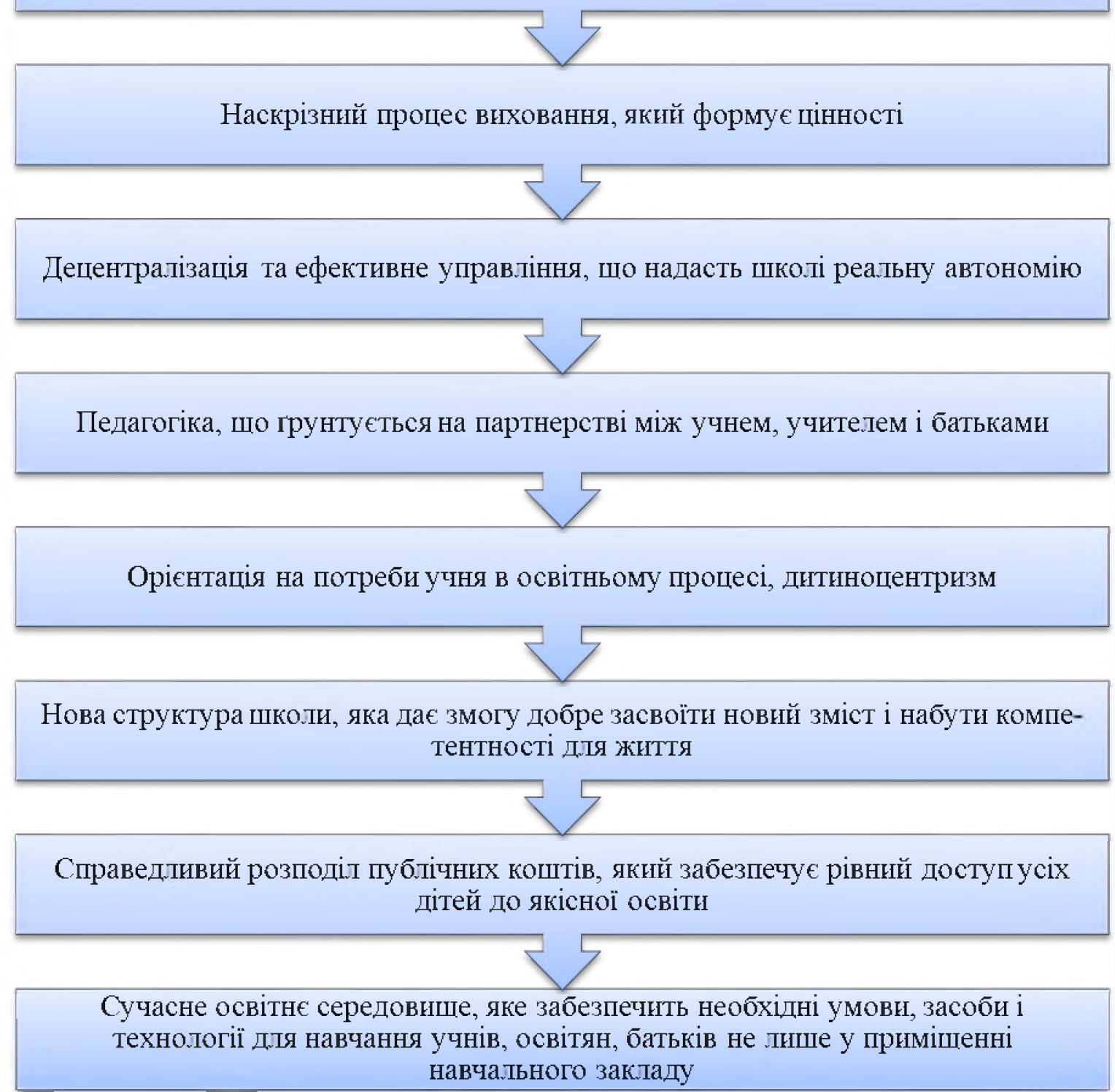

Складено автором за [2, с. 13].

Рис. 2. Основні положення НУШ щодо формуваня компетентностей

Сучасний учитель, опираючись на ці положення, реалізовує мету і завдання мовно-літературної освітньої галузі. Формулювання завдань відбувається відповідно до запропонованих змістових ліній. У типових програмах О. Савченко та Р. Шияна вони подібні, однак не тотожні. 
О.Савченко у програмі для 1-2 класів виокремлює наступні змістові лінії: "Взаємодіємо усно", "Читаємо", "Взаємодіємо письмово", "Досліджуємо медіа", “Досліджуємо мовні явища” і формує основні завдання (рис.3).

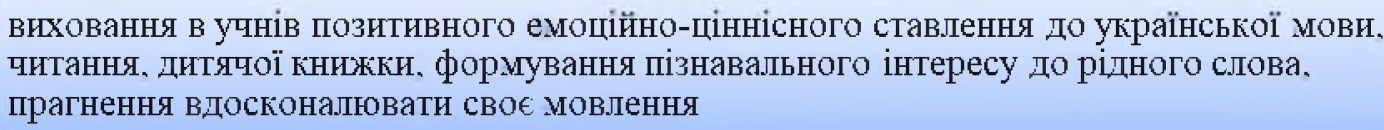

формування умінь опрацьовувати тексти різних видів (художні. науково-популярні. навдальні. медіатексти)

дослідження мовних одиниць і явищ з метою опанування поцаткових лінгвістичних знань і норм української мови

залучення молодших школярів до практичного застосування умінь 3 різних видів мовленнєвої діяльності в навдальнгх і жнттєвих сптуаціях

Складено автором за [4].

Рис. 3. Основні завдання змістових ліній у програмі для 1-2 класу

У програмі для учнів 3-4 класу, розробленій під керівництвом О.Савченко, відсутня змістова лінія "Читання", оскільки авторка по-різному структурує мовнолітературну галузь. Якщо для першого циклу (1-2 класи) передбачено інтегровані курси "Навчання грамоти" та "Українська мова і читання", то для другого циклу (3-4 клас) запропоновано два навчальні предмети "Українська мова", “Літературне читання".

"Пізнаємо простір дитячого читання"; "Розвиваємо навичку читання, оволодіваємо прийомами розуміння прочитаного"; "Взаємодіємо усно за змістом прослуханого"; "Досліджуємо і взаємодіємо 3 текстами різних видів"; "Оволодіваємо прийомами роботи 3 дитячою книжкою"; “Досліджуємо і взаємодіємо з медіапродукцією"; "Перетворюємо та інсценізуємо прочитане; створюємо власні тексти" змістові лінії предмета "Літературне читання".

Змістові лінії предмета "Українська мова" спрямовані на формування в молодших школярів умінь сприймати, аналізувати, інтерпретувати й оцінювати усну інформацію та використовувати їі в різних комунікативних ситуаціях, спілкуватися усно 3 іншими людьми в діалогічній i монологічній формах заради досягнення певних життєвих цілей (“Взаємодіємо усно"); повноцінної навички письма, умінь 
висловлювати свої думки, почуття, ставлення та взаємодіяти 3 іншими людьми в письмовій формі, виявляти себе в різних видах мовленнєво-творчої діяльності (“Взаємодіємо письмово"); умінь аналізувати, інтерпретувати, критично оцінювати інформацію в медіатекстах та використовувати ії для збагачення власного досвіду, створювати прості медіа продукти (“Досліджуємо медіа"); умінь досліджувати мовні одиниці й явища 3 метою опанування початкових лінгвістичних знань, норм літературної вимови та правил українського правопису, формування в молодших школярів умінь послуговуватися українською мовою в усіх сферах життя (“Досліджуємо мовні явища") [5].

Програма О.Савченко містить багато компонентів традиційного вивчення мови та літератури в початковій школі. Інтегрування й діяльнісний підхід, основні ознаки навчання в НУШ, не $є$ наскрізним і обов'язковим методичним аспектом. Відтак їі обирають вчителі, які тяжіють до традиційних підходів та методів навчання, а не інновацій. Іншою причиною, є чіткий розподіл годин.

Мета дослідження полягає в обгрунтуванні особливостей організації мовнолітературної освіти молодших школярів в умовах Нової української школи.

Виклад основного матеріалу дослідження. У контексті започаткованого дослідження особливу увагу приділяємо змістовій лінії "Оволодіваємо прийомами роботи 3 дитячою книжкою", яка "передбачас формування і розвиток в учнів прийомів розрізнення дитячих книжок за жанрово-тематичними ознаками, типом видання (книжка-твір, книжка-збірка, довідник, словник тощо); прогнозування орієнтовного змісту книжки (твору) з опорою на їі ілюстративний та довідково- інформаційний апарат; прийомів самостійного вибору книжок 3 використанням інформаційних ресурсів дитячої бібліотеки; умінь зв'язно висловлювати власні емоційно-оцінні враження щодо змісту прочитаного, складати короткий відгук на прочитану книжку тощо” [5].

Програма, яку розроблено під керівництвом Р. Шияна, у першому циклі передбачено змістові лінії мовно-літературної освітньої галузі: "Взаємодіємо усно", "Читаємо", "Взаємодіємо письмово", “Досліджуємо медіа", “Досліджуємо мовлення”, “Театралізуємо”. Відповідно визначено завдання, які стоять перед учасниками освітнього процесу (рис.4).

Означені завдання й змістові лінії запропоновані й у другому циклі навчання у початковій школі. Розробники програми не змінюють структурування мовно-літературної галузі й провідним обирають інтегрований, діяльнісний підходи. На формування та становлення комунікативної компетентності учнів спрямовані змістові лінії в умовах безпосереднього спілкування“Взаємодіємо усно”, в умовах опосередкованого спілкування (на відстані у просторі та часі) - "Читаємо”, “Взаємодіємо письмово” (автор - читач), “Досліджуємо медіа” (читач / глядач / слухач - автор). Якщо змістова лінія "Взаємодіємо усно" передбачає "залучення учнів до дій зі сприймання, перетворення, виокремлення, аналізу й інтерпретації, оцінювання та використання усної інформації в реальній мовленнєвій практиці (бесіда, дискусія у класі, мікродискусія в групі, обговорення в парі тощо)" [6], то інші названі змістові лінії забезпечують здобуття досвіду опосередкованого спілкування. 
виховання стійкої мотивації до дитання та прагнення вдосконалюватн своє мовлення

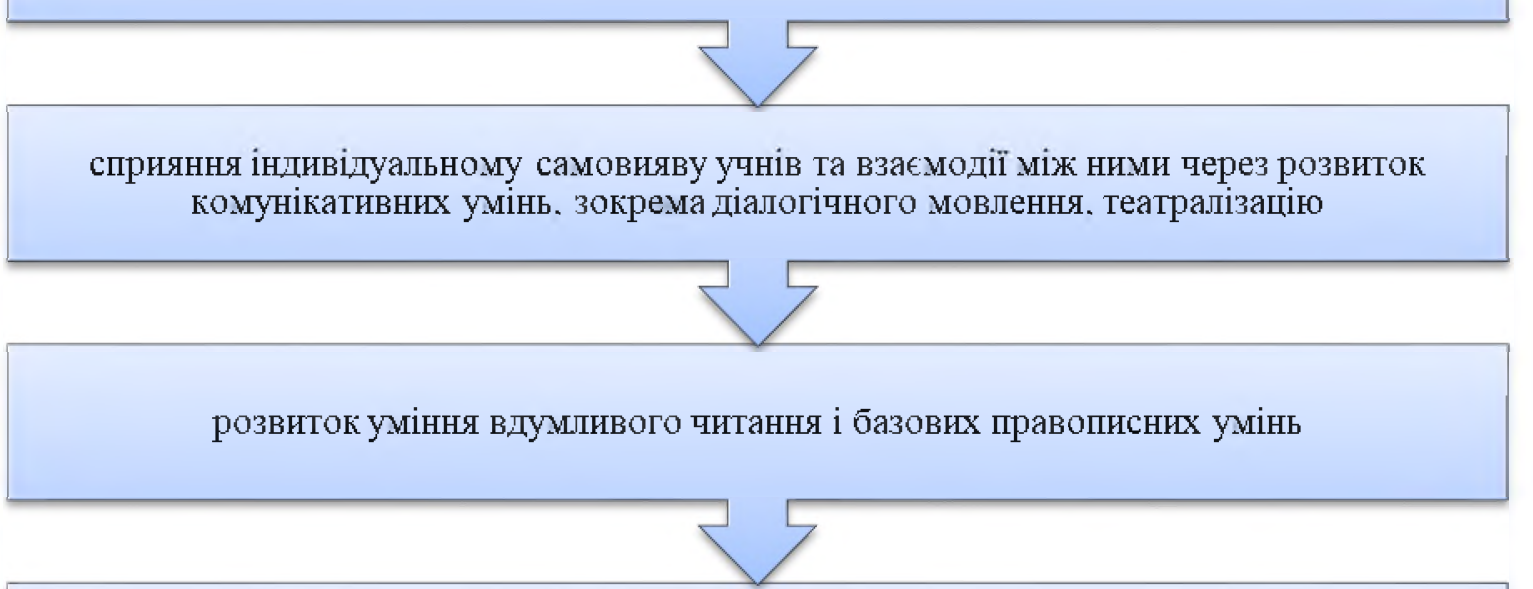

зоагачення духовного світу учнів через естетичне сприймання творів художньоі літератури та медіапродуктів

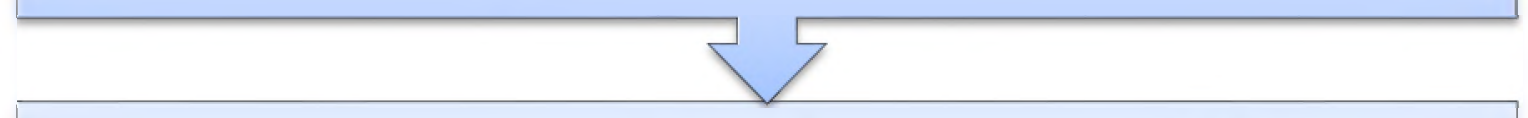

розвиток уяви та творчого мислення учнів за допомогою творів пітератури та мнстецтва, медіатекстів, театралізації, гри

формування умінь опрацьовувати тексти різних вцдів (художні, науковопопулярні, навчальні, медіатексти)

розвиток здатності спостерігати за мовними явншами, експернментувати зі звуками, словамн, фразами, зокрема і в мовнгх іграх, для опанування початковнх лінгвістичннх знань і норм української мовн

створення сприятливого мовного середовнша у школі, зокрема й через пізнання сучасної дитячої літератури різної тематикн та жанрів

Складено автором за [5].

Рис. 4. Завдання змістової лінії мовно-літературної освітньої галузі за програмою Р. Шияна

Під час читання учні розвивають уміння сприймати та аналізувати текст, оцінювати прочитане та перетворювати інформацію, уявляти, мислити творчо. Результатом писемної практики є базові вміння створювати писемні висловлювання у реальному та віртуальному просторі та редагувати їх. Змістова лінія “Досліджуємо медіа" пропонує інструмент для активного критичного освоєння комунікативного медіасередовища.

Змістову лінію “Досліджуємо мовлення” у порівнянні із програмою О. Савченко, у програмі Р. Шияна доповнено завданнями, актуальними у роботі з худож- 
німи текстами. У межах цієї змістової лінії учні опановують виражальні засоби художніх текстів, що в цілому сприяє творенню індивідуального стилю мовлення.

Авторською новацією є виокремлення змістової лінії “Театралізуємо", яка спрямована на розвиток комунікативних умінь учнів, зокрема вміння моделювати різні ситуації спілкування, обирати відповідні комунікативні стратегії, досліджувати несловесні засоби спілкування. як зазначено у програмі, "Специфіка змістової лінії "Театралізуємо" пов'язана 3 формуванням уявлення про театр як місце, де учні здобувають досвід співчуття та співпереживання. Тому в межах змістової лінії “Театралізуємо" учні досліджують чужу (глядач) та власну (актор) експресію. Ця змістова лінія передбачає залучення учнів до сценічної творчості, в умовах якої школярі набувають акторського досвіду, зокрема імпровізаціі, що забезпечує розвиток у дитини емоційного інтелекту, творчого мислення, ініціативності, самосвідомості й самоефективності, уміння мобілізувати інших, долати бар'єри, пов'язані з неоднозначністю, невизначеністю та ризиками, співпрацювати з іншими особами" [6].

Учителі-практики порівнюють і по-різному відгукуються про ці програми. Побутує думка, що програма О. Савченко більш звична, тоді, як програма Р. Шияна “дає більше можливостей для інтеграції $\mathrm{i} \epsilon$ прогресивнішою, але 3 нею виникає чимало бюрократичних проблем, бо незрозуміло, як вести документацію” [3].

Розробники мають власні міркування щодо інтеграції, зокрема інтеграції математики, мови й читання. Олександра Савченко зберігає предмет "Навчання грамоти", який і так інтегрований, "бо поєднує навчання писати, читати і роботу 3 дитячою книжкою. Так було традиційно. Ми вважаємо, що математику не треба поєднувати 3 іншими курсами, бо діти й так вчаться не тільки рахувати, але й просторово мислити, складати моделі, працювати за алгоритмом. Ці предмети і так багатофункціональні". Р. Шиян дотримується іншої думки: “Я негативно ставлюся до того, що мову і математику залишили поза інтеграцією, бо як можна досліджувати світ без неї? Вчителі, які вибрали НУШ-1, мимоволі тї використовуватимуть, однак не системно" [3].

Пропоновані програми різняться й передбаченими очікуваними результатами, які у програмі О. Савченко визначені на кінець кожного класу, а у програмі Р. Шияна - кожного циклу.

Реалізації мовно-літературної освітньої галузі сприяє забезпечення підручниками, яких зараз запропоновано більше десяти, але часто вони не відповідають усім вимогам НУШ. Вибір за якою програмою навчатися робить учитель та відділи освіти. Однак якщо спочатку більшість учителів надавали перевагу програмі О. Савченко, то вже цього річ спостерігається тенденція відмови від традиційного підходу й тяжіння до інтеграції, яку більшою мірою передбачено навчальною програмою Р. Шияна.

Висновки. Отож особливості організації мовно-літературної освіти молодших школярів значною мірою залежать від учителя, який обирає за якою програмою буде навчати учнів, а відтак визначає для себе пріоритети цього навчання: традиційне чи інтегроване, звичне чи інноваційне, спрямоване на формування знань чи зорієнтоване на формування практичних умінь і навичок й реалізацію діяльнісного підходу. Перспективним $є$ порівняльний аналіз методик реалізації змісту й завдань мовно-літературної галузі, поширених у практиці сучасної початкової школи.

\section{Література}

1. Вольфовська Т. Становлення інтерактивних умінь як психологічна проблема інтеграції особистості в суспільне життя. Педагогіка і психологія, 2002. № 4. 
2. Джежелей О.В. Навчаємо слухати, говорити, читати. Початкова иєкола, 1994. № 6. С. 17.

3. Круль Л., Городецька О. Читацький інтерес як складова дитячого читання та читацької культури. Інформаційний бюлетень кафедри фахових методик $і$ технологій початкової освіти: збірник наукових пращь. Івано-Франківськ, ПП Бойчук А. Б., 2019. № 3. Частина 2. С. 119-125.

4. Розвиток читацьких інтересів засобами аналізу та інтерпретації художнього твору: енциклопедія [автор-упоряд. В.А.Юрчак]. Черкаси : ЧОППОП, 2013. 32 с.

5. Розмова Софії Заклецької з Мар'яною Савкою, співзасновником “Великого Їжака". Мар'яна Савка: "Наша дитяча література принципово відрізняється від інших дитячих літератур перш за все чудовою дитячою поезією". URL: http://bukvoid.com.ua/digest/2012/01/17/140506.html (Дата звернення: 24.10.2019).

6. Савченко О. Літературне читання. 3 клас. К.: "Освіта", 2013. 198 с.

\section{References}

1. Volfovska T. Stanovlennia interaktyvnykh umin yak psykholohichna problema intehratsii osobystosti v suspilne zhyttia. Pedahohika i psykholohiia, 2002. № 4.

2. Dzhezhelei O.V. Navchaiemo slukhaty, hovoryty, chytaty. Pochatkova shkola, 1994. № 6. S. 17.

3. Krul L., Horodetska $\mathrm{O}$. Chytatskyi interes yak skladova dytiachoho chytannia ta chytatskoi kultury. Informatsiinyi biuleten kafedry fakhovykh metodyk i tekhnolohii pochatkovoi osvity: zbirnyk naukovykh prats. Ivano-Frankivsk, PP Boichuk A. B., 2019. № 3. Chastyna 2. S. 119-125.

4. Rozvytok chytatskykh interesiv zasobamy analizu ta interpretatsii khudozhnoho tvoru: entsyklopediia [avtor-uporiad. V.A.Iurchak]. Cherkasy : ChOIPOPP, 2013. $32 \mathrm{~s}$.

5. Rozmova Sofii Zakletskoi z Marianoiu Savkoiu, spivzasnovnykom "Velykoho Yizhaka". Mariana Savka: "Nasha dytiacha literatura pryntsypovo vidrizniaietsia vid inshykh dytiachykh literatur persh za vse chudovoiu dytiachoiu poeziieiu". URL: http://bukvoid.com.ua/digest/2012/01/17/140506.html (Data zvernennia: 24.10.2019).

6. Savchenko O. Literaturne chytannia. 3 klas. K.: "Osvita", 2013. 198 s.

Одержано статтю: 18.09 .2019

Прийнято до друку: 11.10.2019

УДК $376-056.36$

DOI: $10.15330 /$ esu. $17.346-351$

\section{Тетяна Кудярська,} викладач, ДВНЗ “Прикарпатський національний університет імені Василя Стефаника" (м. Івано-Франківськ, Україна)

\section{Tetiana Kudiarska,}

Lecturer, Vasyl Stefanyk Precarpathian National university (Ivano-Frankivsk, Ukraine)

tetianakudiarska@ukr.net

\section{ТЕОРЕТИЧНІ І ПРАКТИЧНІ ПІДХОДИ ДО ВПРОВАДЖЕННЯ ІНКЛЮЗИВНОӤ ОСВІТИ: СУЧАСНІ НАУКОВІ ДОСЛІДЖЕННЯ}

\section{THEORETICAL AND PRACTICAL APPROACHES TO THE IMPLEMENTATION OF INCLUSIVE EDUCATION: CURRENT RESEARCH}

Стаття присвячена аналізу прачь вітчизняних вчених, які займалися вивченням питания впроваджения інклюзивної освіти в Украйні, визначення основних категоріальних понять, теоретико-методологічних основ формування новітніх підходів до організачіі освітнього проџесу в інклюзивних закладах, аргументації доичльності застосування спечифічних навчально-виховних засобів. Особлива увага у статті приділяється проблемі кадрового забезпечення інклюзивної освіти, необхідності створення команди фахівців для спільної роботи з дитиною з особливими освітніми потребами в кожному випадку зокрема. Наведено приклади структури готовності майбутніх фахівиів до роботи в початковій иколі як з здоровими дітьми, так і з дітьми з особливостями психофізичного розвитку. 